Article

\title{
New Puppets in the Old School: The Applicability of Traditional Internationalisation Theories in the Sharing Economy
}

\author{
Cristina Pérez-Pérez * (D), Diana Benito-Osorio (D) and Susana María García-Moreno (D)
}

check for updates

Citation: Pérez-Pérez, Cristina, Diana Benito-Osorio, and Susana María García-Moreno. 2021. New Puppets in the Old School: The Applicability of Traditional Internationalisation Theories in the Sharing Economy. Administrative Sciences 11: 98. https://doi.org/ 10.3390/admsci11030098

Received: 29 July 2021

Accepted: 4 September 2021

Published: 9 September 2021

Publisher's Note: MDPI stays neutral with regard to jurisdictional claims in published maps and institutional affiliations.

Copyright: (c) 2021 by the authors. Licensee MDPI, Basel, Switzerland. This article is an open access article distributed under the terms and conditions of the Creative Commons Attribution (CC BY) license (https:// creativecommons.org/licenses/by/ $4.0 /)$.
Business Administration (ADO), Applied Economics II and Foundations of Economic Analysis, Universidad Rey Juan Carlos, Paseo de los Artilleros s/n, 28032 Madrid, Spain; diana.benito@urjc.es (D.B.-O.); susanamaria.garcia@urjc.es (S.M.G.-M.)

* Correspondence: Cristina.perez.perez@urjc.es

Abstract: Sharing Economy platforms have expanded their operations all around the globe at an unexpected rate. Due to its "asset-lite" nature, traditional internationalisation theories may not be able to fully explain or predict their expansion patterns. This lack of theoretical background puts at risk the phenomenon's future and stops traditional companies from coming up with a solid plan to compete against platforms. To ease the creation of a Sharing Economy internationalisation paradigm, this paper intends to review the existing research regarding the internationalisation of sharing platforms as well as the applicability of existing theories. Through a systematic literature review, the existing research was reviewed, and afterwards, internationalisation theories and their distinct factors extracted were noted to address the applicability of these within the singularities of the sharing phenomenon. This classification of factors was done according to the exiting literature in the field. After this research, we can confirm the lack of explanatory power of traditional theories regarding sharing platforms and confirm the insufficient research regarding these operations. We propose a list of factors that should be considered for future research as a guideline for the further development of the Sharing Economy internationalisation theory. Additionally, the factors classification is tested upon the case of the internationalisation of Blablacar, the most extensive carpooling network operating, to check if the theoretical and the practical approaches converge.

Keywords: sharing economy; platforms; internationalisation; internationalisation theories; new theory; growth methods; expansion; conceptualization; Blablacar

\section{Introduction}

The platform business model has grown both in size and scale dramatically over the last decade, and has contributed to driving up productivity in multiple ways (Evans and Gawer 2016), proving not to be fragile or a temporary notion (Fan et al. 2019). This system has been celebrated by consumers and investors (Wirtz et al. 2019) by achieving an unprecedented rate of global success (Parente et al. 2018), despite not having a clear definition (Botsman 2013; Frenken and Schor 2017; Sundararajan 2014). Instead of focusing on developing and commercializing products, this model concentrates its efforts on creating an efficient and convenient virtual marketplace that connects users and allows them to match accordingly to time, place, and individual preferences (Parente et al. 2018).

With an expected market value of \$335 billion by 2025 (Statista 2020) and millions of direct and indirect employees, platforms have become a significant economic force and a global phenomenon (Evans and Gawer 2016). To maximise the payoffs, SE platforms have expanded quickly to other countries, in some cases without taking enough time to evaluate how to adapt their methods and strategies, resulting in mixed results from these internationalisation processes (Kozlenkova et al. 2021). This international expansion has attracted a great deal of attention, but most questions related to these processes still need 
to be addressed by the literature (Kozlenkova et al. 2021; Parente et al. 2018). Although, in general, the SE is a recent concept, the academic interest in this area is continuously growing (Sassanelli et al. 2019), boosted by the request for answers by traditional companies and the society in general, which are concerned about the legality and fairness of this competitive model (Dunne 2017) and their long-term impact on communities all around the world (Marchi and Parekh 2016).

According to Marano et al. (2020), SE platforms seem to be less challenged by internationalisation-related challenges than traditional companies, and, at the same time, platforms have been said to be able to formulate novel ways of international expansion (Nambisan et al. 2019), extricating themselves from existent paradigms. Although, assessing the size of the sharing sector is difficult (Schor and Vallas 2021). In a survey carried out by the Center for a New American Dream (2014), between 10\% and 14\% of Americans had participated in a sharing exchange. Regarding Europe, and according to ING Bank's (2015) study, around a third of Europeans consumers have heard of the sharing economy, and around 5\% have declared to participate actively on it during the previous year. This same study anticipated the growth that was about to come within the coming years, which was mainly driven by technological innovations, cultural practices, the economic conditions, and the Great Recession, together with the discourses of SE founders and designers (Schor and Vallas 2021). By enacting a new way of work, which offers a more flexible and personalise schedule (Sundararajan 2016), lower entry barriers and a more inclusive environment for people from all types of backgrounds (Zanoni 2019) the SE has expanded all over the world at an unprecedent rate, challenging both, traditional companies, and scholars.

By taking into consideration this information, the main objective of this paper is to review the most prominent international theories, and point out how they can be used to explain the internationalisation processes of SE platforms and where they fail to do so. With this paper, we aim to understand the applicability of traditional theories in the SE and open new research paths to formulate a new custom-made theory that takes into consideration the SE specificities. Therefore, during this research, the following research questions will be addressed:

RQ1: Are existent internationalisation theories able to explain the foreign expansion processes of SE platforms?

RQ2: How can the SE specific characteristics interfere in the applicability of internationalisation theories?

This study is the first attempt to analyse the applicability of the factors derived from the main internationalisation theories and comes justified by several reasons. First, it presents an overview of the current internationalisation theories and their key factors. Second, by analysing the SE in this context, the relevance of each factor can be evaluated under the perspective of this model, which will allow sifting among those factors which can be useful when explaining internationalisation processes and those which are not. This sieving will confirm if any of the actual theories is fully applicable to this model, and in the opposite case, which factors should be considered when analysing the expansion processes. Finally, by bridging the disconnect between the SE model and the internationalisation theories, we aim to provide a foundation for future research regarding these processes and stimulate this discussion.

To shed light on this theoretical question, the case of Blablacar's internationalisation process was analysed under this new perspective. This platform is the world's leading long-distance carpooling platform, with a community of 80 million drivers, passengers in 22 countries and 600 employees (Mogavero 2020). It contributes to bringing people closer and creating a unique space and has double the occupancy rate of cars, contributing to carbon-saving. Moreover, this platform, among other examples as Lift or Ola, has changed the old-fashioned mobility systems worldwide (Wirtz et al. 2019) without owning any vehicles (Mogavero 2020). 
To reach the objectives set, first, both topics are reviewed, and the relationship between them and their most important aspects exposed. Afterwards, these two elements will be combined and analysed in deep to distort the factors according to their applicability. These results will be applied to the case of Blablacar's internationalisation process. Finally, the discussion and the conclusion section will be addressed, going through the principal results, and showing the way for the further advancement of the field.

\section{Literature Review}

With the rise of information technology in the late 20th century, the spread of personal computers, mobile communication and location-based services, the global consumption scheme is changing (Kim and Suh 2021). Furthermore, factors such as the abundance of idle capacity, the growing awareness regarding sustainability, and the economic recession, which implies higher unemployment rates, have constituted the perfect environment for the EC to flourish (Cheng 2016; Kathan et al. 2016). This system offers more convenient access and the possibility of gaining profits from underutilised assets (Cheng 2016; Kathan et al. 2016; Parente et al. 2018), and returns, in some way, to the consumption method followed in the pre-industrial era, when people lived in smaller communities and used to share their limited resources thanks to mutual trust and previous experience (Hawksworth 2014).

This phenomenon has been named as: "Collaborative Economy", "Access economy", "Collaborative consumption" or "Sharing Economy", with this last name being the most widely used. Although there is still no agreement on defining this model (Botsman 2013; Frenken and Schor 2017; Lamberton and Rose 2012), it has some characteristics widely agreed among scholars. These include aspects, such as the critical role played by digital platforms (Möhlmann 2015; Munkøe 2017; Stokes et al. 2014; Tussyadiah 2016) or the reputation systems incorporated within them (Allen and Berg 2014; Frenken 2017; Munkøe 2017). In addition, the elimination of idle capacity of goods (Allen and Berg 2014; Richardson 2015), the preference of access over ownership (Dredge and Gyimoothy 2015; Lindblom et al. 2018; Perren and Grauerholz 2015), or the community of peers (Frenken 2017; Hamari et al. 2016; Perren and Grauerholz 2015), that builds up around platforms (Alonso-Almeida et al. 2020; Baumber et al. 2019; Kassan and Orsi 2012), are considered relevant as well.

Due to the lack of agreement when it comes to defining the phenomenon, different classifications have arisen as well. For example, according to Schor (2016), platforms can be classified depending on the platform orientation (for-profit/non-profit), and the type of provider involved (peer-to-peer/business-to-peer). For Frenken et al. (2015), the SE is compound by three elements: a costumer-to-costumer interaction, temporary access, and a more efficient use of physical resources. If only two out of these three elements are present, they no longer consider it SE, but another economic form of exchange, on demand economy (customer-to-customer and access), second-hand economy (customer-to-customer and goods), or product-service economy (access and goods). Oskam and Boswijk (2016) divided value networks in four groups according to two dimensions. From this analysis, open and not-for-profit systems were identified, as well as peer-to-peer market places based on open systems, closed protected systems for the common good (called collectives) and hyperconnected and distributed platforms with a commercial goal (network capitalists). These different definitions and classifications lead to a very disorganised research field as well as to difficulties with collecting and processing information to obtain empirical data, which results in a lack of official statistics (Schor and Vallas 2021).

In general, it could be said that through this system, similarly to multi-sided marketplaces or triadic business model (service enabler-service provider-customer), platforms rely on information technologies to allow different agents to share their assets and to find a substitute alternative to ownership (Parente et al. 2018). The success of this model relies on the strength of this interaction (Kumar et al. 2018). In addition, this shift from bilateral to multilateral relationships allows members to have varying and dynamic roles through their time within the platform (Nambisan et al. 2019). The effects of the SE continues to trigger an intense debate among scholars (de Streel and Larouche 2015), and traditional 
industries are opening to newcomers which compete with existing companies through different strategies and methods (Russo and Stasi 2016), challenging traditional ways of doing business and changing the global organization of economic activities (Vitkovic 2016).

Due to the virtual nature of the platforms, users access them through web browsers or mobile apps, which means that they can be used all around the world, allowing them to be international "by default" (Shaheer and Li 2020). Although this opportunity is presented, most platforms make deliberate foreign market entry decisions (Stallkamp and Schotter 2019) expanding aggressively and not being conditioned by cultural or economic discrepancies (Parente et al. 2018). However, these internationalisation decisions are often made without much information, making platforms unsure of how to proceed (Coviello et al. 2017), resulting in different degrees of success (Kozlenkova et al. 2021). This quick international expansion has attracted a significant amount of attention (Parente et al. 2018), but this is a topic still to be developed, which could have its foundations in traditional business theories.

International business strategy has been an area of interest for many years, which has contributed to the development of different theories aiming to explain the processes undertaken by companies. Traditionally, these theories were focused on large multinational corporations (Johanson and Vahlne 2009; Mtigwe 2006), but the focus recently has been on the analysis of smaller companies, international new ventures, and born-global companies, as they seem to internationalise faster and differently (Oviatt and McDougall 2005; Smith et al. 2012).

Although the internationalisation research field has increased over the last few decades, literature dealing with the internationalisation of SE platforms is almost non-existent (Parente et al. 2018; Stallkamp and Schotter 2019). This is relevant because traditional internationalisation-related challenges are less relevant for SE firms (Marano et al. 2020), and, therefore, underlying reasons for internationalisation may be different. Due to their nature, there is a need to formulate novel ways of international expansion models (Nambisan et al. 2019), as although traditional theories could be considered, their theoretical assumptions are significantly challenged by this new system (Parente et al. 2018).

From traditional international business literature, three main perspectives can be found aiming to explain internationalisation processes (Table 1) (Akter et al. 2019; Andersson 2000; Burgel et al. 2001). These three domains identify how internationalisation has been explained through previous theories, either by growth and expansion, or though strategies and methods, therefore considering an internationalisation theory any paradigm which study:

Table 1. Summary of the review of internationalisation theories.

\begin{tabular}{|c|c|c|c|}
\hline Theories & Key Assumptions & Derived Factors & Authors \\
\hline \multicolumn{4}{|c|}{ Economic View of Internationalisation (Macro Level) } \\
\hline $\begin{array}{l}\text { Product Life Cycle } \\
\text { Theory }\end{array}$ & $\begin{array}{l}\text { The life cycle of the firm's product } \\
\text { is linked to internationalisation }\end{array}$ & $\begin{array}{l}\text { Nature of product } \\
\text { Stage in the life cycle }\end{array}$ & Vernon (1966) \\
\hline $\begin{array}{l}\text { The Monopolistic } \\
\text { Advantage Theory }\end{array}$ & $\begin{array}{l}\text { Highlights the role of the individual } \\
\text { firm as the main determinant of } \\
\text { international flows of goods and } \\
\text { capital }\end{array}$ & $\begin{array}{l}\text { Firm's competitive advantage } \\
\text { Product's superior value }\end{array}$ & Hymer (1976) \\
\hline Internalisation Theory & $\begin{array}{l}\text { Firms internationalise to reduce } \\
\text { costs }\end{array}$ & $\begin{array}{l}\text { Cost reduction } \\
\text { Opportunity to the } \\
\text { intermediate suppliers }\end{array}$ & Buckley and Casson (1976) \\
\hline $\begin{array}{l}\text { The Eclectic Theory of } \\
\text { Internationalisation }\end{array}$ & $\begin{array}{l}\text { Firms internationalise due to } \\
\text { ownership advantages, location } \\
\text { advantages, and } \\
\text { internationalisation advantages }\end{array}$ & $\begin{array}{l}\text { Labour costs } \\
\text { Barrier to trade } \\
\text { Transport costs } \\
\text { Product's heritage value }\end{array}$ & Dunning (1979) \\
\hline
\end{tabular}


Table 1. Cont.

\begin{tabular}{|c|c|c|c|}
\hline Theories & Key Assumptions & Derived Factors & Authors \\
\hline \multicolumn{4}{|c|}{ Resource-Based View of Internationalisation (Firm Level) } \\
\hline $\begin{array}{l}\text { Resource-Advantage } \\
\text { Theory }\end{array}$ & $\begin{array}{l}\text { Assumes that the international } \\
\text { resources of a firm influence the } \\
\text { internationalisation of small } \\
\text { business }\end{array}$ & $\begin{array}{l}\text { Firm's performance } \\
\text { Firm's territorial location }\end{array}$ & Barney (1991) \\
\hline $\begin{array}{l}\text { Competency-Based } \\
\text { Theory }\end{array}$ & $\begin{array}{l}\text { Foreign investment decisions are } \\
\text { heavily influenced by the unique } \\
\text { managerial competencies of } \\
\text { entrepreneurs }\end{array}$ & $\begin{array}{l}\text { Managerial competencies } \\
\text { Management know-how }\end{array}$ & Collis (1991) \\
\hline Human Capital Theory & $\begin{array}{l}\text { The ability to be an exporter may } \\
\text { not be solely related to the age or } \\
\text { size of the business, it is also related } \\
\text { to the human capital of an } \\
\text { entrepreneur }\end{array}$ & $\begin{array}{l}\text { Entrepreneur's international } \\
\text { business skills } \\
\text { Entrepreneur's international } \\
\text { orientation } \\
\text { Entrepreneur's environmental } \\
\text { perceptions } \\
\text { Entrepreneur's management } \\
\text { know-how }\end{array}$ & $\begin{array}{l}\text { Bates (1998); Gimeno et al. } \\
\text { (1997); Kalleberg and Leicht } \\
\text { (1991); Ruzzier et al. (2007); } \\
\text { Westhead (1995) }\end{array}$ \\
\hline
\end{tabular}

Behavioural View of Internationalisation

\begin{tabular}{|c|c|c|c|}
\hline $\begin{array}{l}\text { The Foreign Investment } \\
\text { Decision Process }\end{array}$ & $\begin{array}{l}\text { Assumes that decisions regarding } \\
\text { foreign investment encompass a } \\
\text { behavioural process triggered by a } \\
\text { stimulus to invest. }\end{array}$ & Time and effort pressure & Aharoni (1966) \\
\hline $\begin{array}{l}\text { Uppsala/Stage Model of } \\
\text { Internationalisation }\end{array}$ & $\begin{array}{l}\text { Firms gradually increase their } \\
\text { internationalisation operations in } \\
\text { different stages as they develop } \\
\text { knowledge, experience, and } \\
\text { relationships with international } \\
\text { markets }\end{array}$ & $\begin{array}{l}\text { Foreign market knowledge } \\
\text { Past experience } \\
\text { Relationships with foreign } \\
\text { partners } \\
\text { Foreign language }\end{array}$ & $\begin{array}{l}\text { Johanson and Vahlne (1977) } \\
\text { Ruzzier et al. (2007) } \\
\text { Johanson and Vahlne (2009) }\end{array}$ \\
\hline
\end{tabular}

Firms start involving in international trade with those countries having psychologically distinct features. Export activities

I-Model vary for small firms depending on the decision-makers of the firm. The process of decision-making is the key to the process of internationalisation.

Past or present experience Exploration for market knowledge

Previous experience and reputation, founders learning and positive behaviour
Bilkey and Tesar (1977)

Czinkota (1982)

Reid (1981)
Emphasise personal relationships as the key factor to enter the international market.
Personal networking Johanson and Mattsson (1987) Munro and Coviello (1995) Laforet and Tann (2006)
Internationalisation
Internationalisation is dependent on contingent on the nature of the knowledge. The quality and nature of knowledge developed by an organization and its deployment are dependent on the institutional settings and social communities where the firm is located. 
Table 1. Cont.

\begin{tabular}{|c|c|c|c|}
\hline Theories & Key Assumptions & Derived Factors & Authors \\
\hline $\begin{array}{l}\text { Process Theory of } \\
\text { Internationalisation }\end{array}$ & $\begin{array}{l}\text { The internationalisation process of a } \\
\text { firm is initiated in a reactive mode } \\
\text { in response to unsolicited export } \\
\text { orders. Spontaneous international } \\
\text { orders provide entrepreneurs to } \\
\text { accumulate knowledge of } \\
\text { internationalisation and learn both } \\
\text { their organization's capabilities as } \\
\text { well as international market needs. }\end{array}$ & $\begin{array}{l}\text { International orders } \\
\text { Experience in international } \\
\text { transactions } \\
\text { Firm's perception }\end{array}$ & Vernon (1966) \\
\hline $\begin{array}{l}\text { New Venture/Born } \\
\text { Global Firm's Theory of } \\
\text { Internationalisation }\end{array}$ & $\begin{array}{l}\text { Early accumulation of experiential } \\
\text { knowledge facilitates early } \\
\text { internationalisation. Firms focus on } \\
\text { niche markets and global networks } \\
\text { and reoriented towards developing } \\
\text { mutually beneficial relationships } \\
\text { with international partners. }\end{array}$ & $\begin{array}{l}\text { Experiential knowledge } \\
\text { Role of founder/entrepreneur }\end{array}$ & $\begin{array}{l}\text { McDougall et al. (1994) } \\
\text { Oviatt and McDougall (2005) } \\
\text { Bell et al. (2003) } \\
\text { Li and Li (2007) }\end{array}$ \\
\hline Strategic Choice Theory & $\begin{array}{l}\text { Firms evaluate the risks in changing } \\
\text { market opportunities and respond } \\
\text { strategically to internationalisation } \\
\text { efforts. }\end{array}$ & $\begin{array}{l}\text { Vision } \\
\text { Knowledge, skills, experience }\end{array}$ & Shuman and Seeger (1986) \\
\hline Adaptive Choice Model & $\begin{array}{l}\text { Internationalisation is an adaptive } \\
\text { response to other challenging } \\
\text { environments, imposed on } \\
\text { organizations. }\end{array}$ & $\begin{array}{l}\text { Declining local demand } \\
\text { Increase demand in foreign } \\
\text { markets } \\
\text { Risk of adapting to change }\end{array}$ & $\begin{array}{l}\text { Lam and White (1999) } \\
\text { Havnes and Senneseth (2001) }\end{array}$ \\
\hline
\end{tabular}

Source: Prepared by the authors after Akter et al. (2019).

Economic Perspective: The economic perspective, based on Smith (1776) and Ricardo (1891) conceptualise internationalisation as an independent phenomenon for profitmaximization, and places the firm's distinctive advantage central to internationalisation and conjectures rationally (Seifert 2010).

Resource-Based View Perspective: This theory, initially proposed by Penrose (1960), and actualised several other times by authors like Wernerfelt (1984) and Barney (1991), became the dominant paradigm in strategic planning (Barney et al. 2001) and later, an influential approach in internationalisation research (Peng 2001). Through this theory, the internationalisation of companies is explained as an adaptive response to environmental complexity, with the aim of gaining a competitive advantage by organizing the resources, skills, and routines (Teece et al. 1997).

Behavioural Perspective: Behavioural theories of internationalisation appeared as an alternative to the economic view of internationalisation (Akter et al. 2019). The central assumptions of behavioural theories of internationalisation are: (1) path dependency; (2) goal complexity; (3) contextual contingency; and (4) weak rationality requirements (Seifert 2010). This perspective has provided a solid background for new perspectives on understanding internationalisation.

\section{Methodology}

The qualitative research here has involved a systematic literature review (Grant and Booth 2009; Petticrew and Roberts 2006; Tranfield et al. 2003) to investigate the previous research analysing the relationship between the SE and the internationalisation of the platforms. The main goal of this step is to check if there is any specific research that analyses the internationalisation of SE platforms, and if so, what has been said about these processes.

The search strategy was based on the bibliographic database Web of Science (WoS) Core Collection, as it is the most widely accepted and frequently used database for the 
analysis of scientific publications (Castillo-Vergara et al. 2018; Dzikowski 2018; GuerrasMartín et al. 2020; Yang et al. 2013).

We identified the research area for the systematic review and studied the scope and objectives, setting the SE as the central concept. Afterwards, we determined the inclusion and exclusion criteria. All of the articles and reviews in the database containing the keywords "sharing economy", "collaborative economy", or "platform economy" were retrieved. This approach yielded a total of 2564 results. The sample was downloaded and reviewed to remove duplicates and confirm their fit within the model. The authors undertook this process manually, including 1898 papers in the final database. This search was conducted in April 2021.

For this specific research, a subgroup of publications was analysed, selecting from the previous sample those articles that relate the sharing economy with the internationalisation processes, including those papers studying specific cases. Again, the documents were individually reviewed by the authors to confirm their fit within the topic. In addition, selected references from the articles identified were carefully screened for other relevant studies.

After the initial query, the sample was personally revised by the authors to eliminate non-related papers and possible duplicates. Once this step had been undertaken, the remaining papers were analysed in depth. Several new articles were included because they appeared in the bibliography of some of the selected papers and dealt with the topic in question. Finally, nine papers were identified that studied the relationship between the SE platform and internationalisation (Figure 1). These nine studies can be found in Table 2.

The next step was analysing which of the factors extracted from existing internationalisation theories can be used to explain the internationalisation process of SE platforms. First, the internationalisation theories were examined, and their most representative factors noted to study. Afterwards, these factors were individually addressed from a theoretical point of view to analyse if, according to previous literature regarding the SE, its characteristics and processes, each individual element could be used to explain the international expansion activities of platforms. In order to address the applicability of the factors, and due to the lack of literature regarding these specific processes, general literature regarding the SE was used, relating the internationalisation factors extracted with the closest existent literature. The reasoning behind the classification of each element is explained in detail in Sections 4.1-4.3, and summarised in Table 3, where the factors, their suitability and the literature supporting the classification are presented. After this process, the resulting division of factors was tested on the case of the internationalisation process of Blablacar, to check if the theory driven classification was true in a practice driven example.

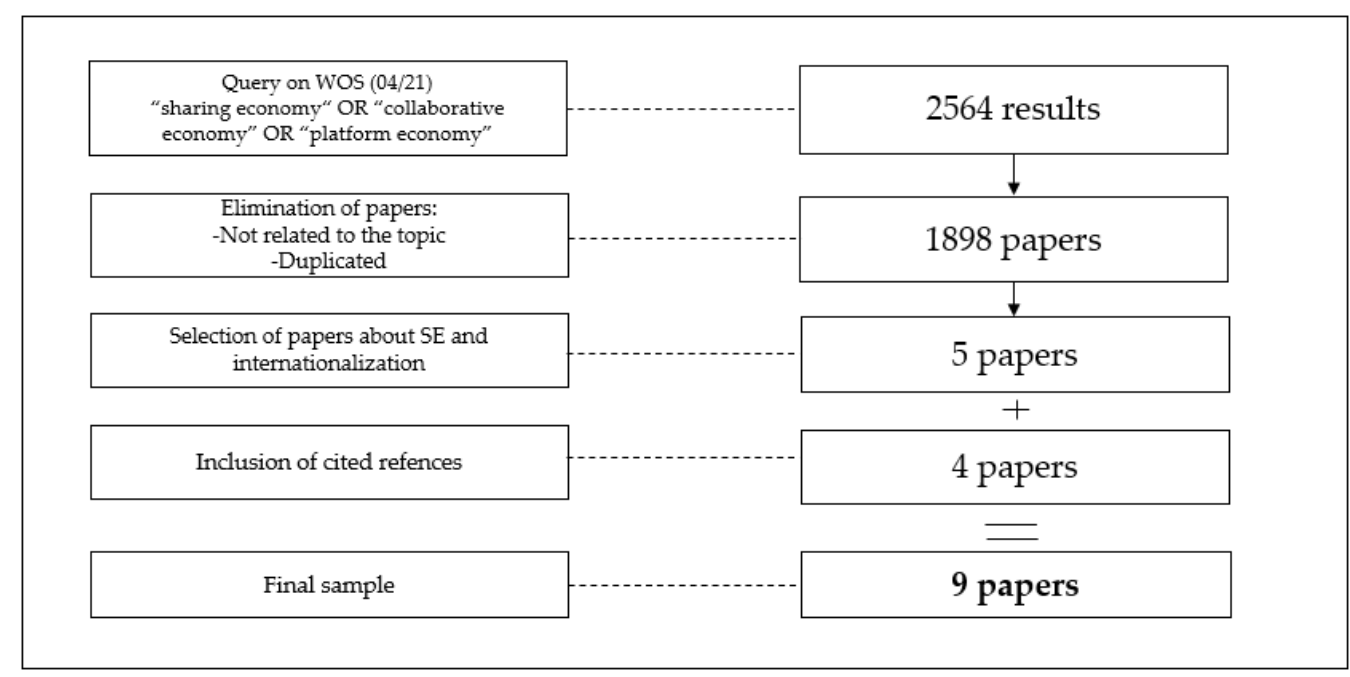

Figure 1. Criteria for selecting papers. 
Table 2. Final sample of papers regarding the internationalisation of sharing platforms.

\begin{tabular}{|c|c|c|c|}
\hline Author(s)/Year & Article & Journal & Main Conclusions \\
\hline Kim and Suh (2021) & $\begin{array}{l}\text { Spreading the sharing } \\
\text { economy: Institutional } \\
\text { conditions for the } \\
\text { international diffusion of } \\
\text { Uber, 2010-2017 }\end{array}$ & PLOS ONE & $\begin{array}{l}\text { - The SE has the potential to be a substitute } \\
\text { of traditional economic transactions. } \\
\text { - There are certain external environments } \\
\text { which allow the SE to flourish. } \\
\text { - The SE is not only an emergent industry, } \\
\text { but a whole set of social relationships } \\
\text { among the agents. } \\
\text { Platforms are destined to compete with } \\
\text { conventional companies to expand their } \\
\text { operations. }\end{array}$ \\
\hline Kozlenkova et al. (2021) & $\begin{array}{l}\text { Sharing economy: } \\
\text { International marketing } \\
\text { strategies }\end{array}$ & $\begin{array}{l}\text { Journal of } \\
\text { international } \\
\text { business studies }\end{array}$ & $\begin{array}{l}\text { - The lack of a unify SE definition has } \\
\text { hindered the accurate understanding of the } \\
\text { expansion of platforms. } \\
\text { There are some key drivers that need more } \\
\text { research to explain the SE effectiveness } \\
\text { across countries. } \\
\text { There is a complex pattern of global } \\
\text { contingencies that platforms need to } \\
\text { consider when entering international } \\
\text { markets. }\end{array}$ \\
\hline Marano et al. (2020) & The liability of disruption & $\begin{array}{l}\text { Global strategy } \\
\text { journal }\end{array}$ & $\begin{array}{l}\text { - Traditional internationalisation-related } \\
\text { challenges are less relevant for SE } \\
\text { platforms than traditional firms. } \\
\text { - The key platform's features like their } \\
\text { "asset-lite" nature explain these differences. } \\
\text { - Institutional characteristics may play } \\
\text { against platforms, which are challenging } \\
\text { industry-specific expectations and rules. }\end{array}$ \\
\hline
\end{tabular}

Online Platform Providers in the Sharing Economy:

Lehdonvirta et al. (2019) Emergence of New Service Suppliers?
Journal of world trade
- $\quad$ The growth of the SE challenges domestic and international economic structures and policies.

- There is an incompatibility between platforms and international trade regime.

- $\quad$ Platforms originated in developed economies have "leadership" advantages when entering emerging economies.

The influence of socia embeddedness on organizational legitimacy and the sustainability of the globalization of the sharing economic platform: Evidence from Uber China

\section{Resources} conservation and recycling
- Organizational legitimacy, in the internationalisation contact, is both and external and internal adaptation process.

- Localization success of international platforms depend on different dimensions of embeddedness and their interactions.
- $\quad$ There is a need to develop new concepts and related constructs to facilitate the adoption of platforms lens in internationalisation theories.

International

Business Studies _ New internationalisation models need to be developed and validated that include specific concepts regarding the SE 
Table 2. Cont.

\begin{tabular}{|c|c|c|c|}
\hline Author(s)/Year & Article & Journal & Main Conclusions \\
\hline $\begin{array}{l}\text { Stallkamp and Schotter } \\
\text { (2019) }\end{array}$ & $\begin{array}{l}\text { Platforms without borders? } \\
\text { The international strategies of } \\
\text { digital platform firms }\end{array}$ & $\begin{array}{l}\text { Global strategy } \\
\text { journal }\end{array}$ & $\begin{array}{l}\text { - Platforms wishing to internationalise need } \\
\text { to consider the scope of direct and indirect } \\
\text { network externalities. } \\
\text { - Network externalities influence the } \\
\text { international expansion of platforms. } \\
\text { - Within-country and cross-country network } \\
\text { externalities affect internationalisation } \\
\text { decisions. }\end{array}$ \\
\hline Parente et al. (2018) & $\begin{array}{l}\text { The sharing economy } \\
\text { globalization phenomenon: A } \\
\text { research agenda }\end{array}$ & $\begin{array}{l}\text { Journal of } \\
\text { International } \\
\text { Management }\end{array}$ & $\begin{array}{l}\text { - The widespread adoption of platforms } \\
\text { across the world is one of the fastest and } \\
\text { largest internationalisation movement. } \\
\text { - } \quad \text { Previous IB literature provide only a partial } \\
\text { explanation of the behaviour of SE } \\
\text { platforms. } \\
\text { The ecosystem approach to SE } \\
\text { internationalisation should encompass } \\
\text { different IB perspectives. } \\
\text { Platforms internationalisation relies on } \\
\text { their reach for multisided ecosystem } \\
\text { players' engagement. }\end{array}$ \\
\hline Anwar (2018) & $\begin{array}{l}\text { Growing global in the sharing } \\
\text { economy: Lessons from Uber } \\
\text { and Airbnb }\end{array}$ & $\begin{array}{l}\text { Global Business } \\
\text { and } \\
\text { Organizational } \\
\text { Excellence }\end{array}$ & $\begin{array}{l}\text { - } \\
\text { Platforms can take advantage of } \\
\text { first-mover opportunities when entering a } \\
\text { new country, as well as covering niche } \\
\text { opportunities. } \\
\text { Brand management and distinctive } \\
\text { business models are key aspects for } \\
\text { success. } \\
\text { Consumer loyalty and the constant seek of } \\
\text { new opportunities are essential to the } \\
\text { platforms' success. }\end{array}$ \\
\hline
\end{tabular}

Table 3. Derived factors from internationalisation theories and their role in the SE.

\begin{tabular}{lll}
\hline \multicolumn{1}{c}{ Derived Element } & Suitability for SE & \multicolumn{1}{c}{ Authors } \\
\hline Nature of product & $\boldsymbol{V}$ & Parente et al. (2018); Wirtz et al. (2019) \\
\hline Stage in the life cycle & $\boldsymbol{V}$ & Frenay (2018); Marano et al. (2020) \\
\hline Firm's competitive advantage & $\boldsymbol{N}$ & $\begin{array}{l}\text { Chasin et al. (2018); Nambisan et al. (2019); Stallkamp and } \\
\text { Schotter (2019); Wirtz et al. (2019) }\end{array}$ \\
\hline Product's superior value & X & Kozlenkova et al. (2021); Rogers (2016); Wirtz et al. (2019) \\
\hline Cost reduction & X & Wirtz et al. (2019) \\
\hline Opportunity to be an intermediate supplier & X & Wirtz et al. (2019) \\
\hline Labour costs & $\boldsymbol{V}$ & $\begin{array}{l}\text { Anwar (2018); Frenay (2018); Parente et al. (2018); Wirtz } \\
\text { et al. (2019) }\end{array}$ \\
\hline Barriers to trade & X & $\begin{array}{l}\text { Anwar (2018); Felländer et al. (2015); Kozlenkova et al. } \\
\text { (2021) }\end{array}$ \\
\hline Transport costs & X & Anwar (2018); Frenay (2018); Parente et al. (2018) \\
\hline Product's heritage value & & Evans and Gawer (2016); Parente et al. (2018) \\
\hline
\end{tabular}


Table 3. Cont.

\begin{tabular}{|c|c|c|}
\hline Derived Element & Suitability for SE & Authors \\
\hline Firm's performance & $x$ & Kozlenkova et al. (2021); Ochieng and Takawira (2020) \\
\hline Firm's territorial location & $X$ & Frenay (2018) \\
\hline Entrepreneur/Manager characteristics & $\approx$ & Wirtz et al. (2019) \\
\hline Time and effort pressure & $\approx$ & Felländer et al. (2015); Ochieng and Takawira (2020) \\
\hline Foreign market knowledge & $\approx$ & $\begin{array}{l}\text { Frenay (2018); Kozlenkova et al. (2021); Ochieng and } \\
\text { Takawira (2020) }\end{array}$ \\
\hline Past experience & $\approx$ & Kozlenkova et al. (2021); Ochieng and Takawira (2020) \\
\hline Relationship with foreign partners & $\approx$ & $\begin{array}{l}\text { Mogavero (2020); Ochieng and Takawira (2020); Parente } \\
\text { et al. (2018); Wirtz et al. (2019) }\end{array}$ \\
\hline Foreign language & $\approx$ & $\begin{array}{l}\text { Marano et al. (2020); Mascareñas Pérez (2011); Stallkamp } \\
\text { and Schotter (2019) }\end{array}$ \\
\hline Exploration for market knowledge & $x$ & Kozlenkova et al. (2021); Ochieng and Takawira (2020) \\
\hline Quality of knowledge & $x$ & Ochieng and Takawira (2020) \\
\hline International orders & $x$ & Anwar (2018) \\
\hline Experience in international transactions & $\approx$ & Ochieng and Takawira (2020) \\
\hline Firm's perception & $x$ & Marano et al. (2020); Nambisan et al. (2019) \\
\hline Experiential knowledge & $x$ & Kozlenkova et al. (2021) \\
\hline Vision & $\approx$ & Anwar (2018) \\
\hline Declining local demand & $x$ & Liu and Chen (2020); Razeghian and Weber (2019) \\
\hline Increase demand in foreign markets & $\checkmark$ & Anwar (2018); Evans and Gawer (2016); Frenay (2018) \\
\hline
\end{tabular}

\section{Results from the Applicability of Selected Factors from Internationalisation Theories within the Sharing Model}

The first step of the process was searching for papers analysing the internationalisation of the SE. Table 2 presents the final sample of documents obtained after applying the different criteria stablished.

After corroborating the statement about the scarcity of research regarding the internationalisation processes, selected theories were tested upon the sharing model. Table 3 shows a list of derived factors from internationalisation theories (included in the last column of Table 1) and their expected suitability to explain the internationalisation expansion of SE platforms according to previous literature of the field. Some of these factors were grouped with other similar ones. In order to make this classification, and due to the small amount of specific literature regarding the internationalisation processes, general literature about the SE field was used. Therefore, previous literature was checked to analyse how each specific element would interact the SE characteristics and attributes, and therefore infer if, at the time of international expansion, that element would be relevant when explaining the methods and decision behind the operation.

\subsection{Non-Influential Factors}

The main goal of platforms is to provide a common land for users, therefore, platforms do not undertake any production activity nor generate costs further than those which arise from the platform maintenance and responsible for this. By being "asset-lite" (Parente et al. 2018) and relying upon their users' goods to provide their service, platforms do not benefit from any cost reduction by operating in one or another location, neither general labour nor transport costs (Anwar 2018; Frenay 2018; Parente et al. 2018; Wirtz et al. 2019). This implies that the search for lower production costs is not as influential for sharing platforms as it is for traditional companies. 
By acting as an intermediary between users, platforms do not have suppliers, so they cannot be influenced by the chance of being an intermediate supplier. According to Wirtz et al. (2019), platforms have disintermediated industries by facilitating people to transact directly with one another in unprecedented ways (Caldieraro et al. 2018). As platforms do not focus on developing or commercializing products, but in creating an efficient marketplace to connect users (Parente et al. 2018), the product's heritage value cannot influence the internationalisation decision.

The relationship between firm performance and internationalisation does not seem relevant, as platforms usually do not wait to have a solid performance in the home country before moving to others (Kozlenkova et al. 2021; Ochieng and Takawira 2020). Due to their specific characteristics, platforms will be influenced to a lesser extent by risks (Brouthers et al. 2016) than traditional companies. This lack of relevant risks could be a critical factor in the accelerated internationalisation process, as they can start operating internationally before any company following a traditional business model could (Parente et al. 2018). This lack of risks and the flexibility inherent to the model (Nambisan et al. 2019) places the firm's territorial location as a less relevant factor when making the internationalisation decision. Digital businesses have implied the "death of distance" (Cairncross 2001) due to its ease when expanding through the use of the internet and technologies. Hence, the territorial location is not an inhibiting factor anymore.

The exponential growth of the SE (Frenay 2018) supposes that this model is known and present almost anywhere, so platforms can, at least, foresee the success opportunities of their business in different locations. This fact can be considered advantageous as platforms do not need to adventure in new countries to explore and increase their market knowledge. From the begging, platforms can know the market conditions or have easy access to locals who can provide with knowledge (Ochieng and Takawira 2020), which influences speeding up internationalisation processes (Kozlenkova et al. 2021) and the establishment in said location. By being able to access local knowledge, the information or experience accumulated by platforms before the establishment in new countries is not much. However, this factor does not hinder their expansion intentions. Regarding this factor, older platforms could have a slight advantage over younger competitors (Anwar 2018).

The SE has proved that it is neither a tendency nor a temporal phenomenon (Fan et al. 2019). Although its popularity has increased over the years and it is possible to find platforms almost anywhere, internationalisation decisions are not based on demands of potential users in other locations or client chasing strategies. Instead of basing their decisions on international orders, platforms seek opportunities to broaden their business portfolio (Anwar 2018). As previously indicated, the risks assumed by platforms are, theoretically, smaller than those assumed by traditional companies, so the risk perception is lower as well (Nambisan et al. 2019). The "asset-light" condition of these platforms reduces the size of the investment needed to enter new markets, allowing a rapid expansion and limiting asset exposure (Marano et al. 2020). Due to the novelty of the SE field, and although the industry is in different life stages depending on the country to be analysed, neither of them can be considered to be in a mature or declining stage, so the main reason behind the internationalisation of platforms is not a decline in the local demand, but the opportunity to keep growing in potentially successful locations (Liu and Chen 2020; Razeghian and Weber 2019).

Finally, platforms businesses are more flexible than traditional businesses. This characteristic allows them to adapt quickly to changes (Wirtz et al. 2019), therefore not being so much influenced by other competitors' decisions. Although there is an increasing number of multi-country platforms (Kim and Suh 2021), there is still a significant proportion of non-internationalise equally successful ones, so, therefore, it cannot be said that platforms are internationalizing because of an adaptive response to challenging environments, but rather are deciding on their own when, where, and under which conditions they want to internationalise (Parente et al. 2018). 


\subsection{Influential Factors}

Due to the nature of the operation carried out through SE platforms (Parente et al. 2018; Wirtz et al. 2019) the internationalisation is fundamentally different from traditional companies, mainly in terms of speed, scope and territorial expansion (Frenay 2018; Marano et al. 2020). Instead of offering any product or service, these platforms aim to create a shared virtual space to connect people with similar needs (Alonso-Almeida et al. 2020; Hamari et al. 2016; Stokes et al. 2014). This mainly digital nature allows platforms to expand their operations within territorial spaces almost from creation (Shaheer and Li 2020).

As commented previously, the novelty of the SE places it in the first stages of its lifecycle, although it can vary among these first stages depending on the territorial location. This growth has led platforms to invade markets (Frenay 2018) and enjoy rapid global growth opportunities (Marano et al. 2020). This rapid growth has been influenced by the platform's characteristics and its way of achieving competitive advantages. According to Chasin et al. (2018), these competitive advantages depend on having a big community of users, both on the supply and the demand side, and therefore create interconnections among partners (Nambisan et al. 2019). The more local users that both sides of the network have, the more attractive it will be for new users (Stallkamp and Schotter 2019). Since sharing platforms do not possess any other source of competitive advantage, as difficult to imitate assets (Parente et al. 2018), this generation of a network of users is a critical factor for their internationalisation. In the same way, platforms generate value by leveraging the resources and users of communities, lowering transaction costs and fostering trust and ecosystem governance (Wirtz et al. 2019). According to Rogers (2016), these platforms deliver value differently from traditional businesses, achieving a differentiation degree that translates into a higher perceived value by users (Kozlenkova et al. 2021).

The growth experienced by platforms has, on some occasions, has been hindered by different barriers, as legal and regulatory problems (Dunne 2017; Vitkovic 2016). These laws can affect platforms and the experience of users (Kozlenkova et al. 2021) as they can see their experience modified due to these limitations. In addition to the legal barriers and the reaction from local competitors (Felländer et al. 2015), platforms need to take into consideration other kinds of barriers as trust, sustainability and societal issues or institutional concerns (Anwar 2018; Kozlenkova et al. 2021; Marano et al. 2020). Regarding this last aspect, factors related to the local institutional conditions affect the platforms internationalisation decisions (Tsukanova 2019). According to Uzunca et al. (2018), countries with lower levels of institutionalization may be more accessible for platforms to enter and achieve power due to their lower barriers and the ease for platforms to gain society's approval.

Finally, as it has been stated before, over recent years, the SE has experienced exponential growth in terms of users, platforms and industries where it is possible to find collaborative alternatives (Anwar 2018). This global tendency of access preference has sped up the internationalisation process (Frenay 2018), and platforms have become an important economic force (Evans and Gawer 2016). Together with the better exploitation of market imperfection by platforms (Parente et al. 2018; Razeghian and Weber 2019), this fact has created a perfect environment for the SE to grow and expand their operations all over the world.

\subsection{Potentially Influential Factors}

There are some other factors that, while not being indispensable, may help explain platforms' internationalisation decisions. The quick speed of growth within the SE has benefited most platforms, although it has brought some challenges. Due to this speed, platforms willing to internalise have felt the urge to take quick decision, which on some occasions has been an advantage and in other a drawback. According to Ochieng and Takawira (2020), those first-mover platforms have faced many disadvantages as competitors were aware of their decisions to avoid their errors and take advantage of their knowledge. On the other hand, some platforms were willing to take these risks, as the benefits of first 
movers outweigh the disadvantages (Felländer et al. 2015). However, wishing to enter a location as quickly as possible, platforms can ignore their lack of knowledge regarding the local conditions (Frenay 2018) or forget to adapt their strategies to the country-specific factors. These facts may be the main reason for many unsuccessful operations (Kozlenkova et al. 2021), becoming, therefore, a relevant factor to take into account when expanding operations cross-borders.

In order to avoid as many threats as possible, platforms might tend to internationalise in those countries in which they can achieve context-specific advantages (Nambisan et al. 2019) and where the local conditions are similar to those faced in previous countries (Kozlenkova et al. 2021). The study of demographic characteristics and usage patterns can help determine the most advantageous conditions for the SE to flourish (Kumar et al. 2018; Shaheen et al. 2017) and decide future destinations based on said data. Among these conditions, the local language may be a determinant factor for some platforms. They may find it easier to enter countries with similar languages (Ochieng and Takawira 2020; Stallkamp and Schotter 2019). Meanwhile, this factor may not be relevant for other platforms, as platform software can be translated easily without incurring high costs (Marano et al. 2020).

Although the SE is characterised by their aim for growth and expansion (Anwar 2018), their past experience can condition this expansion, for example, regarding the speed (Ochieng and Takawira 2020) or the evaluation of local conditions (Kozlenkova et al. 2021) in order to avoid previous errors or repeat successful strategies, as for example collaborations. By complementing their system with complementary asset provides, for example, insurance companies (Mogavero 2020), platforms can manage their ecosystem and assure a sufficient number of users on both sides (Parente et al. 2018) as well as achieve an excellent knowledge about local conditions (Ochieng and Takawira 2020). Furthermore, these alliances may influence internationalisation decisions by encouraging platforms to expand to those countries where their partners are present or a higher chance to reach agreements.

Finally, when talking about factors related to the entrepreneur/manager figure, contrary to the born global companies, which mainly depend on the entrepreneur will to internationalise (Bouncken et al. 2014; Kuivalainen et al. 2012), there is no evidence of SE platforms being highly dependent on the entrepreneur goals and perceptions. In contrast to traditional business, platforms require a management team that facilitates a strong network connection, controls all resources orchestration, and fosters liquidity and quality matching (Wirtz et al. 2019). Rather than being dependent on the manager's skills, orientation, perception, or know-how, platforms seem more motivated by external factors, such as the popularity of the sharing model in the target country, government decisions, or population characteristics (Ochieng and Takawira 2020).

\section{The Applicability of Traditional Internationalisation Factors to Platforms: The Blablacar Case}

Blablacar (established in France in 2006) is an online platform offering carpooling services, connecting people who need to travel with drivers who have empty seats (Cruz et al. 2018). Blablacar posts itself as the world's leading carpooling community which enables low-cost city-to-city travel by connecting people with drivers going the same way. This platform has 90 million users and is present in 22 countries, with 25 million travellers per quarter (Blablacar 2021), and by combining their ability for identifying share ride opportunities with the SE growth, they have come up to an efficient and popular system. By merging social media with a reservations platform, a feeling of trust and safety was achieved, contributing to the company's establishment (Shaheen et al. 2017). With the vision of bringing fairness, freedom, and fraternity to the world of travel, this platform has revolutionised the mobility sector in Europe.

Blabacar's main business relies on providing a common land for people who have free seats in their cars and people wishing to travel (Mogavero 2020), offering a trendy and innovative product. This new consumption alternative did not only offer a better value in economic terms, but it did also rely on a more sustainable and environmentally friendly 
option (Font and McCabe 2017), addressing two highly requested topics by users. Due to its recent appearance, both the $\mathrm{SE}$ and Blablacar can be considered to be in the growth stage of their life cycle, or nascent market (Casprini et al. 2019), characterised by growing demand and by the expansion of platforms (Klepper 1997). This is the general situation, together with the high aggregated value this alternative has achieved by granting access to goods which, otherwise many users could not access it, has meant that Blablacar has achieved a competitive advantage and a product differentiation resulting from the big and efficient global network of users (Casprini et al. 2019). By achieving a balance between the supply and demand of car seats, the platform reached a point of efficiency in which they believed they had a product that could be successful in different countries (Shaheen et al. 2017). Therefore, by relying upon factors, such as the nature of their product, their stage along the life cycle, or their competitive advantage achieved through the superior value of their product and the network of users created, Blablacar decided to take a step toward internationalisation.

As pointed before, the use of technological means and the mainly online nature of platforms suppose that their cost structure is fundamentally different from traditional business, implying lower costs associated with internationalisation processes and lower operating costs (Gilibert and Ribas 2019). Although Blablacar has been expanding into different countries, their headquarters have stayed in France, their home country, complemented with regional offices in some specific settings to provide users with a close, knowledgeable contact according to their location in the globe, and constituting this with a corporate strategy (Aversa et al. 2021). By establishing their offices where most needed are, instead of where the lower costs are located, in operating, labour, and transport terms, the platform is proving that their internationalisation steps are not toward lower costs but towards better and more efficient service for all agents involved and a wider range of options for their users.

At the moment of the first internationalisation, the number of users and car seats offered in France was still rising (Shaheen et al. 2017). Although the platform was not facing a decrease in their numbers, the generalization of the SE tendency along different countries was a growth opportunity, as although there was not an explicit request for these services, there were countries that presented an ideal set of circumstances that favoured Blablacar's business model implementation (Zalega 2020). Due to these being their first steps towards the international expansion, neither the platform nor the management team, which was more focused on programming and web services (Blablacar 2021), had enough accumulated experience or knowledge about the foreign markets as to be influenced when making decisions, an aspect which change as the platform gain experience and started following a quicker internationalisation rhythm. Although before undergoing the first expansion, Blablacar waited until having a solid performance in their home country, after this first expansion, the pace becomes quicker and the performance less relevant, which fits in with the idea of a gradual "foreign gateway market" followed by quick internationalisation decisions (Ochieng and Takawira 2020).

As shown in Table 4, in the beginning, Blablacar expanded its operations in close countries, which have a greater chance of having similar demand structures and socio-economic conditions. It could be said here that, in this case, they are following an incremental internationalisation. By aiming at this, the process could be smoother, and the challenges faced less demanding (Kozlenkova et al. 2021). Even though each country has its particular institutional conditions, by expanding into countries which are not only neighbours and therefore similar in cultures, but also into countries which operate under similar institutions, as the European Union, Blablacar was able to design an expansion strategy which could be applied in several countries at the same time. As the platform expanded into different countries, the virtual space was translated into local languages, facilitating its adoption by users (Blablacar 2021). Although these factors had a higher relevance at the beginning of the internationalisation process, as Blablacar acquired experience, they began 
to lose importance, and the platform expanded its operations into additional locations and different cultures.

Table 4. Blablacar internationalisation process.

\begin{tabular}{|c|c|}
\hline Date of Internationalisation & Countries Entered \\
\hline 2010 (January) & Spain \\
\hline 2011 (June) & United Kingdom \\
\hline 2012 (May) & Italy \\
\hline \multirow{3}{*}{2012 (October) } & Portugal \\
\hline & Benelux (Belgium, The Netherlands and Luxemburg) \\
\hline & Poland \\
\hline 2013 (April) & Germany \\
\hline \multirow{2}{*}{2014 (January) } & Ukraine \\
\hline & Russia \\
\hline 2014 (September) & Turkey \\
\hline 2015 (January) & India \\
\hline \multirow{4}{*}{2015 (March) } & Hungary \\
\hline & Romania \\
\hline & Croatia \\
\hline & Serbia \\
\hline 2015 (April) & Mexico \\
\hline 2015 (November) & Brazil \\
\hline \multirow{2}{*}{2016 (January) } & Czech Republic \\
\hline & Slovakia \\
\hline
\end{tabular}

By being one of the pioneering platforms in carpooling of Europe (Mogavero 2020), Blablacar benefited from some monopolistic advantages, as their early start provided them with some years of experience and accumulated knowledge, which allowed them to take advantage of market imperfections and create a network of users who, although having alternatives, would still rely on their platform. To keep their users loyal and stay ahead of possible changes in the industry, Blablacar started building relations with different agents to offer complementary products to their main one. The most well-known one is their collaboration with the insurance company Axa (Gassot 2017), which oversees covering any incident that arises during a trip among members of Blablacar. This partnership allowed the platform to start charging a fee to every transaction made between users, which percentage changed according to the length of the trip and the anticipation of the booking (Mogavero 2020). Although this measure was controversial among users, Blablacar justified it with the new incorporation of the insurance service, which added an extra safety point to the service.

Apart from this, additional services were added to Blablacar recently: buses and soon trains. By doing this, the platform is not only securing their innovative company image, which assists on renew themselves and boost their competitive advantages (Calabrò et al. 2016) but also fulfils the same need, travel from one place to another, by different means. This helps to reach a higher potential market share, and therefore building an ecosystem of services for the community (Gassot 2017). These new operations and the previous ones and the internationalisation processes have been funded through funding rounds, the most recent one in April 2021. This funding round secures financial stability to the platform to keep working toward their main goal, facilitate mobility between places with shared transportation (Dillet 2021). This compatibility strategy can lead into a new phenomenon and influence on the travel mode choice of urban residents (Lu et al. 2019). 


\section{Discussion}

After analysing the case of Blablacar, we can say that traditional internationalisation theories cannot fully explain the process undertaken by platforms. In this specific case, the analysis of the extracted factors resulted in the expected results, with some exceptions (Table 5). Blablacar started its international expansion process in countries with a small psychic distance, expanding later into more distant ones (Gassot 2017). This can be explained by the fact that the platform's home country is located in the middle of the European continent, which places them in an ideal location to expand their processes into several neighbour countries at the same time. Contrary to expectations, in this case, the platform's performance was a key factor for the first internationalisation process (Shaheen et al. 2017). However, it lost most of its value as the expansion consolidated and Blablacar started operating into more countries. Finally, although according to the co-founder and $\mathrm{CEO}$, the actual strategy of Blablacar is focusing on their actual operating countries instead of keeping expanding their activities (Dillet 2021), given the funding data and the growth expectancies, this platform keeps positioning itself as the leading carpooling company of Europe and a referent company in the mobility sector in general.

Table 5. Applicability of the extracted factor on Blablacar.

\begin{tabular}{|c|c|c|}
\hline Derived Factor & Expected Result & Feasibility for Blablacar \\
\hline Nature of product & $\checkmark$ & $\checkmark$ \\
\hline Stage in the life cycle & $\checkmark$ & $\checkmark$ \\
\hline Firm's competitive advantage & $\checkmark$ & $\checkmark$ \\
\hline Product's superior value & $\checkmark$ & $\boldsymbol{v}$ \\
\hline Cost reduction & $x$ & $x$ \\
\hline Opportunity to be an intermediate supplier & $x$ & $x$ \\
\hline Labour costs & $x$ & $x$ \\
\hline Barriers to trade & $\checkmark$ & $\boldsymbol{v}$ \\
\hline Transport costs & $X$ & $X$ \\
\hline Product's heritage value & $x$ & $x$ \\
\hline Firm's performance & $x$ & $\boldsymbol{\nu}$ \\
\hline Firm's territorial location & $x$ & $\checkmark$ \\
\hline Entrepreneur/Manager characteristics & $\approx$ & $X$ \\
\hline Time and effort pressure & $\approx$ & $x$ \\
\hline Foreign market knowledge & $\approx$ & $\checkmark$ \\
\hline Past experience & $\approx$ & $x$ \\
\hline Relationship with foreign partners & $\approx$ & $\boldsymbol{\nu}$ \\
\hline Foreign language & $\approx$ & $x$ \\
\hline Exploration for market knowledge & $x$ & $x$ \\
\hline Quality of knowledge & $x$ & $x$ \\
\hline International orders & $x$ & $x$ \\
\hline Experience in international transactions & $\approx$ & $x$ \\
\hline Firm's perception & $x$ & $x$ \\
\hline Experiential knowledge & $x$ & $x$ \\
\hline Vision & $\approx$ & $\boldsymbol{V}$ \\
\hline Declining local demand & $x$ & $X$ \\
\hline Increase demand in foreign markets & $\checkmark$ & $\checkmark$ \\
\hline
\end{tabular}


Previous literature had already acknowledged the lack of research regarding the internationalisation processes within this model (Stallkamp and Schotter 2019) and the need to formulate a new theory due to the different challenges faced and methods followed by sharing platforms (Marano et al. 2020; Nambisan et al. 2019). This paper has corroborated these statements by verifying that none of the existing theories can be fully applied to the SE model. Sharing platforms share some attributes of ibusiness (Brouthers et al. 2016) and triadic business models (Ochieng and Takawira 2020), reflecting on aspects, such as their quicker international expansion (Parente et al. 2018) or the strength of the interaction between users (Kumar et al. 2018), which significantly influence the success of the business model.

When analysing existing internationalisation literature, two big approaches can be found: the gradual internationalisation and the born global (Paul and Rosado-Serrano 2019). Their main difference is that, while the former says that companies will internationalise in countries closer in proximity to the domestic market in terms of physical distance (Johanson and Vahlne 1977), the latter are created to do global business from inception, internationalizing within three years of founding and generating at least $25 \%$ of the total sales in foreign countries (Knight and Cavusgil 2004). Some scholars (Gardinni et al. 2021) suggest that the SE would fit better in the born global model due to their digital nature, asset-free nature, and quick expansion. Although this is a real possibility, more empirical research will be needed to check if platforms fit within this model, as, for example, born global firms are said to need managers with a strong international orientation, which drives them to develop better competitive advantages both in goods and technology (Knight and Cavusgil 2004).

Sharing platforms generate competitive advantages by creating networks of users and facilitating transactions among them, which implies that the bigger the size of the community, the greater value the platform will generate and the more attractive it will be for new users (Stallkamp and Schotter 2019). This suggests that factors related to local culture, features of markets and government positions, and institutionalization factors may affect more of these processes than those factors related to internal aspects of platforms (Razeghian and Weber 2019; Uzunca et al. 2018; Wirtz et al. 2019). On the other hand, factors related to production factors, like transport or labour costs, lose almost all their importance because of the asset-free nature of platforms and the opposite cost structure they have compared to traditional companies (Anwar 2018; Frenay 2018; Kozlenkova et al. 2021; Parente et al. 2018). In the middle of these two extremes, some factors may play an important role for some platforms. Among these factors, some like the relationship with foreign partners (Mogavero 2020; Ochieng and Takawira 2020; Parente et al. 2018; Wirtz et al. 2019), local languages (Marano et al. 2020; Mascareñas Pérez 2011; Stallkamp and Schotter 2019) or the monopolistic advantage achieve by platforms (Anwar 2018; Stallkamp and Schotter 2019) can be found. Contrary to born global companies, in sharing platforms, the role of founders and entrepreneurs is not as determinant in the internationalisation of the company (Wirtz et al. 2019). Through the analysis of these factors, RQ1 was answered, and the applicability of current internationalisation theories was addressed.

Regarding the development of a future theory that addresses the internationalisation processes of SE platforms, considering their singular nature, and as a response to RQ2, it will need to include factors regarding aspects such as the nature of the products/services offered, the level of development of the SE in the location, or the value creation method followed individually by platforms. It should also consider the importance of local conditions, from the social characteristics to the institutional constraints and the technological development of the country or the acceptance towards the online operations. On the other hand, factors related to the production or distribution of goods should be relegated to the background.

\section{Conclusions and Future Research Opportunities}

The SE has proved to be more than a temporary trend and is challenging companies from all around the globe (Parente et al. 2018), while becoming a significant economic force 
at the same time (Evans and Gawer 2016). Due to its specific characteristics, traditional internationalisation theories, which are mainly centred on production and distribution factors, can only provide a partial explanation of why, how, and when sharing platforms internationalise. Therefore, further research within this field is required.

This paper has analysed the potential applicability of existing internationalisation theories in the SE by extracting the most relevant factors of each theory and studying their applicability taking into consideration the singular characteristics of the sharing model. By extracting these factors and studying their suitability, a detailed picture of the applicability of each theory is provided, which will assist scholars when formulating a new theory adapted to the set of characteristics of these platforms. It must be considered that the classification of these factors has a theoretical focus, and it is based on previous literature of the SE field, so when applying them to real examples, some of the factors may act differently from expected. Another limitation of this research comes from the set of internationalisation theories selected and the derived factors, which could be complement with more theories regarding growth strategies. It should be considered as well that the $\mathrm{SE}$ is in constant change and, therefore, research must evolve as platforms do, so what is applicable today, may not be tomorrow. This fact, instead of being a daunting factor for scholars, only encourages the constant development of new research.

In line with the previous statement, the academic implications of this paper come from the fact that, from a theoretical point of view, the reviewed internationalisation theories do not seem to be sufficient when it comes to explain the geographical expansion of sharing platforms, therefore confirming what other authors said previously (Marano et al. 2020; Parente et al. 2018; Stallkamp and Schotter 2019). Although theories cannot be fully applied, some of their more relevant factors seem to influence internationalisation decisions of platforms more than others. By listing the relevant factors, some guidelines are provided for the future development of a theory which can address in a better way these expansion processes. This theory should consider aspects such as the value creation model of platforms, the barriers to trade to face or the institutional conditions. By providing this breakeven point, we expect to foster research regarding the SE in general and their expansion process in specific. This research would not only be helpful for academics researching this topic but also managers of platforms and traditional companies. The former would be able to count on guidelines regarding the steps to follow to have a smooth internationalisation process within the inherent risks of this strategy and achieve a better rate of success. The latter would have been able to have more information regarding the most recent threat to their business model, and the environmental factors that could make their market attractive for sharing platforms. Therefore, they have a more room to manoeuvre when taking steps toward their answer to these questions and doubts raised toward their systems. This paper will also help those reluctant economic entities to realise that the SE is more than a temporary trend and that platforms could pose a problem to their business, as they do not only compete among platforms, but also with their models (Dunne 2017). Finally, there are some governments which are not sure about how to regulate and deal with the SE (Rifkin 2000; Vitkovic 2016) and are delaying this regulation on the grounds that this phenomenon may be temporal. This research can help them realise the international potential of the SE and urge them to look for solutions which accommodate all the implied agents.

To further develop the research field, scholars should analyse in depth the operations already taken by platforms, looking at the previous and posterior data, at the industry involved, at the specific market characteristics, as well as to the reaction of competitors, both from the sharing and traditional field. This research should count on the platforms' managers collaboration, which will assist in obtaining obtain empirical data, testimonies, and motivations, and therefore, count on a more extensive amount of information coming from different sources. 
Author Contributions: Conceptualization, C.P.-P. and D.B.-O.; methodology, C.P.-P. and D.B.-O.; software, C.P.-P.; validation, C.P.-P., D.B.-O. and S.M.G.-M.; formal analysis, C.P.-P. and D.B.-O.; investigation, C.P.-P., D.B.-O. and S.M.G.-M.; resources, C.P.-P., D.B.-O. and S.M.G.-M.; data curation, C.P.-P. and D.B.-O.; writing—original draft preparation, C.P.-P.; writing—review and editing, C.P.-P., D.B.-O. and S.M.G.-M.; visualization, C.P.-P., D.B.-O. and S.M.G.-M.; supervision, D.B.-O. and S.M.G.M.; project administration, D.B.-O. and S.M.G.-M.; funding acquisition, D.B.-O. and S.M.G.-M. All authors have read and agreed to the published version of the manuscript.

Funding: This research received no external funding.

Institutional Review Board Statement: Not Applicable.

Informed Consent Statement: Not Applicable.

Data Availability Statement: Not Applicable.

Conflicts of Interest: The authors declare no conflict of interest.

\section{References}

Aharoni, Yair. 1966. The foreign investment decision process. In Harvard Business School. Boston: Harvard Business School.

Akter, Mansura, Mahfuzur Rahman, and Dragana Radicic. 2019. Women entrepreneurship in international trade: Bridging the gap by bringing feminist theories into entrepreneurship and internationalisation theories. Sustainability 11: 6230. [CrossRef]

Allen, Darcy, and Chris Berg. 2014. The Sharing Economy: How Over-Regulation Could Destroy an Economic Revolution. Institute of Public Affairs. Available online: https://ipa.org.au/portal/uploads/Sharing_Economy_December_2014.pdf (accessed on 12 June 2021).

Alonso-Almeida, María del Mar, Jordi Perramon, and Llorenç Bagur-Femenías. 2020. Shedding light on sharing economy and new materialist consumption: An empirical approach. Journal of Retailing and Consumer Services 52: 101900. [CrossRef]

Andersson, Svante. 2000. The internationalisation of the firm from an entrepreneurial perspective. International Studies of Management E Organization 30: 63-92. [CrossRef]

Anwar, Syed Tariq. 2018. Growing global in the sharing economy: Lessons from Uber and Airbnb. Global Business and Organizational Excellence 37: 59-68. [CrossRef]

Aversa, Paolo, Annelore Huyghe, and Giulia Bonadio. 2021. First impressions stick: Market entry strategies and category priming in the digital domain. Journal of Management Studies. [CrossRef]

Barney, Jay. 1991. Firm resources and sustained competitive advantage. Journal of Management 17: 99-120. [CrossRef]

Barney, Jay, Mike Wright, and David J. Ketchen. 2001. The resource-based view of the firm: Ten years after 1991. Article in Journal of Management 27: 625-41. [CrossRef]

Bates, Timothy. 1998. Survival patterns among newcomers to franchising. Journal of Business Venturing 13: 113-30. [CrossRef]

Baumber, Alex, Moira Scerri, and Stephen Schweinsberg. 2019. A social licence for the sharing economy. Technological Forecasting and Social Change 146: 12-23. [CrossRef]

Bell, Jim, Rod McNaughton, Stephen Young, and Dave Crick. 2003. Towards an Integrative Model of Small Firm Internationalisation. Journal of International Entrepreneurship 1: 339-62. [CrossRef]

Bilkey, Waren J., and George Tesar. 1977. The export behavior of smaller-sized wisconsin manufacturing firms. Journal of International Business Studies 8: 93-98. [CrossRef]

Blablacar. 2021. Blablacar: About Us. Available online: https:/ /blog.blablacar.com/about-us (accessed on 24 July 2021).

Botsman, Rachel. 2013. The Sharing Economy Lacks a Shared Definition. Fast Company, November 21. Available online: https: / / www.fastcompany.com/3022028/the-sharing-economy-lacks-a-shared-definition (accessed on 10 July 2021).

Bouncken, Ricarda B., Felix Schuessler, and Sascha Kraus. 2014. The Theoretical Embedding of Born Globals: Challenging Existing Internationalisation Theories. International Business \& Economics Research Journal (IBER) 14: 39. [CrossRef]

Brouthers, Keith D., Kim D. Geisser, and Franz Rothlauf. 2016. Explaining the internationalisation of ibusiness firms. Journal of International Business Studies 47: 513-34. [CrossRef]

Buckley, Peter J., and Mark Casson. 1976. The Future of the Multinational Enterprise. London: Palgrave Macmillan. [CrossRef]

Burgel, Oliver, Gordon Murray, Andreas Fier, and Georg Licht. 2001. The Rapid Internationalisation of High-Tech Young Firms in Germany and the United Kingdom. Berlin: Springer Science \& Business Media, vol. 22. Available online: https://www.euro-ciss.eu/ fileadmin/user_upload/Redaktion/INTSME/Dokumente/Publikationen/Germany_UK_2.pdf (accessed on 30 May 2021).

Cairncross, Frances. 2001. The Death of Distance: How the Communications Revolution Will Change Our Lives. Boston: Harvard Business Review Press.

Calabrò, Andrea, Tommaso Minola, Giovanna Campopiano, and Thilo J. Pukall. 2016. Turning innovativeness into domestic and international corporate venturing: The moderating effect of high family ownership and influence. European Journal of International Management 10: 505. [CrossRef]

Caldieraro, Fabio, Jonathan Z. Zhang, Marcus Cunha, and Jeffrey D. Shulman. 2018. Strategic Information Transmission in Peer-to-Peer Lending Markets. Journal of Marketing 82: 42-63. [CrossRef] 
Casprini, Elena, Alberto Di Minin, and Andrea Paraboschi. 2019. How do companies organize nascent markets? The BlaBlaCar case in the inter-city shared mobility market. Technological Forecasting and Social Change 144: 270-81. [CrossRef]

Castillo-Vergara, Mauricio, Alejandro Alvarez-Marin, and Dario Placencio-Hidalgo. 2018. A bibliometric analysis of creativity in the field of business economics. Journal of Business Research 85: 1-9. [CrossRef]

Center for a New American Dream. 2014. Analysis Report: New American Dream Survey. Available online: https://newdream.org/ downloads/New_Dream_2014_Poll_Final_Analysis.pdf (accessed on 31 May 2021).

Chasin, Friedrich, Moritz von Hoffen, Benedikt Hoffmeister, and Jorg Becker. 2018. Reasons for failures of sharing economy businesses. MIS Quarterly Executive 17: 185-99. Available online: https:/ /aisel.aisnet.org/misqe/vol17/iss3/4 (accessed on 10 June 2021).

Cheng, Mingming. 2016. Sharing economy: A review and agenda for future research. International Journal of Hospitality Management 57: 60-70. [CrossRef]

Collis, David J. 1991. A resource-Based analysis of global competition: The case of the bearings industry. Strategic Management Journal 12: 49-68. [CrossRef]

Coviello, Nicole, Liena Kano, and Peter W. Liesch. 2017. Adapting the Uppsala model to a modern world: Macro-context and microfoundations. Journal of International Business Studies 48: 1151-64. [CrossRef]

Cruz, Isabel, Rafaela Ganga, and Stefan Wahlen, eds. 2018. Contemporary Collaborative Consumption. Berlin: Springer Fachmedien Wiesbaden. [CrossRef]

Czinkota, Michael. 1982. Export Development Strategies: US Promotion Policy. Westport: Praeger Publishers. Available online: https:/ / pdfs.semanticscholar.org/757a/973b887800e4dab2587a7c1ccd23a147c49b.pdf (accessed on 15 June 2021).

de Streel, Alexandre, and Pierre Larouche. 2015. Disruptive Innovation and Competition Law Enforcement. SSRN Electronic Journal. [CrossRef]

Dillet, Romain. 2021. BlaBlaCar Raises \$115 Million to Build All-in-One Travel App. Available online: https://techcrunch.com/2021 /04/20/blablacar-raises-115-million-to-build-all-in-one-travel-app/?guccounter=1\&guce_referrer=aHR0cHM6Ly93d3cuZ2 9vZ2xlLmNvbS8\&guce_referrer_sig=AQAAALOWoUCaLB-udxA1LLp-6Ta17I0GFNZvGC3ruRTDP5G508NOhC22QHC8 OXyvBX0gcF05_fW3MHKwYtR (accessed on 24 July 2021).

Dredge, Dianne, and Szilvia Gyimoothy. 2015. Collaborative Economy and Tourism: Critical Perspectives, Questionable Claims and Silenced Voices. SSRN Electronic Journal 40: 286-302. [CrossRef]

Dunne, Niamh. 2017. Competition Law (and Its Limits) in the Sharing Economy. In The Cambridge Handbook of the Law of the Sharing Economy. Cambridge: Cambridge University Press, pp. 91-107. [CrossRef]

Dunning, John H. 1979. Explaining Changing Patterns of International Production: In Defence of the Electic Theory. Oxford Bulletin of Economics and Statistics 41: 269-95. [CrossRef]

Dzikowski, Piotr. 2018. A bibliometric analysis of born global firms. Journal of Business Research 85: 281-94. [CrossRef]

Evans, Peter C., and Anabelle Gawer. 2016. The Rise of the Platform Enterprise A Global Survey (Issue 1). Available online: https:/ / www.thecge.net/wp-content/uploads/2016/01/PDF-WEB-Platform-Survey_01_12.pdf (accessed on 24 June 2021).

Fan, Yancheng, Min Xia, Yaguang Zhang, and Yantai Chen. 2019. The influence of social embeddedness on organizational legitimacy and the sustainability of the globalization of the sharing economic platform: Evidence from Uber China. Resources, Conservation and Recycling 151: 104490. [CrossRef]

Felländer, Anna, CLare I. Bogusz, and Robin Teigland. 2015. Sharing Economy: Embracing change with caution. Entreprenörskapsforum. Örebro: Örebro Universitet. [CrossRef]

Font, Xavier, and Scott McCabe. 2017. Sustainability and marketing in tourism: Its contexts, paradoxes, approaches, challenges and potential. Journal of Sustainable Tourism 25: 869-83. [CrossRef]

Frenay, Alexandra. 2018. The Internationalisation of Companies with a Sharing Business Model: A Multiple Case Study of Car-Sharing Platforms. Amsterdam: University of Amsterdam.

Frenken, Koen. 2017. Political economies and environmental futures for the sharing economy. Philosophical Transactions of the Royal Society A: Mathematical, Physical and Engineering Sciences 375: 20160367. [CrossRef]

Frenken, Koen, and Juliet Schor. 2017. Putting the sharing economy into perspective. Environmental Innovation and Societal Transitions 23: 3-10. [CrossRef]

Frenken, Koen, Toon Meelen, Martijn Arets, and Pieter van de Glind. 2015. Smarter Regulation for the Sharing Economy. Available online: https:/ / www.theguardian.com/science/political-science/2015/may/20/smarter-regulation-for-the-sharing-economy (accessed on 29 June 2021).

Gardinni, Marco A., Michael C. Ottenbacher, and Markus Schuckert. 2021. The Routledge Companion to International Hospitality Management. London: Routledge.

Gassot, Yves. 2017. Interview with Frédéric Mazzella Founder, BlaBlaCar, France. Communications \& Strategies 108: 99-103. Available online: https: / / www.proquest.com/docview/2454183423/fulltextPDF/5743D6C8E2BA4FC5PQ/1?accountid=14730 (accessed on 14 June 2021).

Gilibert, Mireia, and Imma Ribas. 2019. Synergies between app-based car-related Shared Mobility Services for the development of more profitable business models. Journal of Industrial Engineering and Management 12: 405. [CrossRef]

Gimeno, Javier, Timothy B. Folta, Arnold C. Cooper, and Carolyn Y. Woo. 1997. Survival of the Fittest? Entrepreneurial Human Capital and the Persistence of Underperforming Firms. Administrative Science Quarterly, 750-83. [CrossRef] 
Grant, Maria J., and Andrew Booth. 2009. A typology of reviews: An analysis of 14 review types and associated methodologies. Health Information \& Libraries Journal 26: 91-108. [CrossRef]

Guerras-Martín, Luis Ángel, Guillermo Armando Ronda-Pupo, José Ángel Zúñiga-Vicente, and Diana Benito-Osorio. 2020. Half a century of research on corporate diversification: A new comprehensive framework. Journal of Business Research 114: 124-41. [CrossRef]

Hamari, Juho, Mimmi Sjöklint, and Antti Ukkonen. 2016. The sharing economy: Why people participate in collaborative consumption. Journal of the Association for Information Science and Technology 67: 2047-59. [CrossRef]

Havnes, Pers A., and Knut Senneseth. 2001. A Panel Study of Firm Growth among SMEs in Networks. Small Business Economics 16: 293-302. [CrossRef]

Hawksworth, John. 2014. The Sharing Economy Has Gone Mainstream. Available online: https://www.financialdirector.co.uk/2014 /09/12/the-sharing-economy-has-gone-mainstream/ (accessed on 13 May 2021).

Hymer, Stephen H. 1976. The International Operations of National Firms: A study of Direct Foreign Investment. Cambridge: MIT Press.

ING Bank. 2015. What Is Mine Is Yours for a Price. Rapid Growth Tipped for the Sharing Economy. Available online: https: //www.ing.com/Newsroom/News/European-sharing-economy-to-grow-by-a-third-in-the-next-12-months.htm (accessed on 7 July 2021).

Johanson, Jan, and Jan-Erik Vahlne. 1977. The Internationalisation Process of the Firm-A Model of Knowledge Development and Increasing Foreign Market Commitments. Journal of International Business Studies 8: 23-32. [CrossRef]

Johanson, Jan, and Jan-Erik Vahlne. 2009. The Uppsala internationalisation process model revisited: From liability of foreignness to liability of outsidership. Journal of International Business Studies 40: 1411-31. [CrossRef]

Johanson, Jan, and Lars-Gunnar Mattsson. 1987. Interorganizational Relations in Industrial Systems: A Network Approach Compared with the Transaction-Cost Approach. International Studies of Management \& Organization 17: 34-48. [CrossRef]

Kalleberg, Arne L., and Kevin T. Leicht. 1991. Gender and Organizational Performance: Determinants of Small Business Survival and Success. Academy of Management Journal 34: 136-61. [CrossRef]

Kassan, Jenny, and Janelle Orsi. 2012. The legal landscape of the sharing. Journal of Environmental Law and Litigation 27: 1-20.

Kathan, Wolfgang, Kurt Matzler, and Viktoria Veider. 2016. The sharing economy: Your business model's friend or foe? Business Horizons 59: 663-72. [CrossRef]

Kim, Hyun J., and Chan S. Suh. 2021. Spreading the sharing economy: Institutional conditions for the international diffusion of Uber, 2010-2017. PLoS ONE 16: e0248038. [CrossRef]

Klepper, Steven. 1997. Industry life cycles. Industrial \& Corporate Change 6: 146-81.

Knight, Gary A., and Tamar S. Cavusgil. 2004. The born-global firm. Journal of International Business Studies 35: 124-41. [CrossRef]

Kogut, Bruce, and Udo Zander. 1993. Knowledge of the Firm and the Evolutionary Theory of the Multinational Corporation. Journal of International Business Studies 24: 625-45. [CrossRef]

Kozlenkova, Irina V., Ju-Yeon Lee, Dandian Xiang, and Robert W. Palmatier. 2021. Sharing economy: International marketing strategies. Journal of International Business Studies. [CrossRef]

Kuivalainen, Olli, Sanna Sundqvist, Sami Saarenketo, and Rod B. McNaughton. 2012. Internationalisation patterns of small and medium-sized enterprises. International Marketing Review 29: 448-65. [CrossRef]

Kumar, Vikas, Avishek Lahiri, and Orhan B. Dogan. 2018. A strategic framework for a profitable business model in the sharing economy. Industrial Marketing Management 69: 147-60. [CrossRef]

Laforet, Sylvie, and Jennifer Tann. 2006. Innovative characteristics of small manufacturing firms. Journal of Small Business and Enterprise Development 13: 363-80. [CrossRef]

Lam, Long W., and Louis P. White. 1999. An adaptive choice model of the internationalisation process. International Journal of Organizational Analysis 7: 105-34. [CrossRef]

Lamberton, Cait P., and Randall L. Rose. 2012. When is Ours Better than Mine? A Framework for Understanding and Altering Participation in Commercial Sharing Systems. Journal of Marketing 9: 34-40. [CrossRef]

Lehdonvirta, Vili, Otto Kässi, Isis Hjorth, Helena Barnard, and Mark Graham. 2019. The Global Platform Economy: A New Offshoring Institution Enabling Emerging-Economy Microproviders. Journal of Management 45: 567-99. [CrossRef]

Li, Wenchen, and Meizi Li. 2007. The effect of entrepreneurship for the internationalisation of SMEs. Paper presented at the 2nd International Forum of Business Education, Lilydale, Australia, September 16-19.

Lindblom, Arto, Taru Lindblom, and Heidi Wechtler. 2018. Collaborative consumption as C2C trading: Analyzing the effects of materialism and price consciousness. Journal of Retailing and Consumer Services 44: 244-52. [CrossRef]

Liu, Xufeng, and Hongmin Chen. 2020. Sharing Economy: Promote Its Potential to Sustainability by Regulation. Sustainability 12: 919. [CrossRef]

Lu, Ke, Jing Zhou, and Xiaowei Lin. 2019. Research on compatibility strategy of ride-hailing platforms. European Journal of International Management 13: 880. [CrossRef]

Marano, Valentina, Stephen Tallman, and Hildy J. Teegen. 2020. The liability of disruption. Global Strategy Journal. [CrossRef]

Marchi, Alberto, and Ellora-Julie Parekh. 2016. How the sharing economy can make its case. McKinsey Quarterly 1: 112-16.

Mascareñas Pérez, Juan. 2011. Fusiones, Adquisiciones y Valoración de Empresas. Madrid: Universidad Complutense Madrid. 
McDougall, Patricia. P., Scott Shane, and Benjamin M. Oviatt. 1994. Explaining the formation of international new ventures: The limits of theories from international business research. Journal Business Ventures, 469-87. Available online: https://www.sciencedirect. com/science/article/pii/ 0883902694900175 (accessed on 10 May 2021). [CrossRef]

Mogavero, Tyler. 2020. Strategic Management of BlaBlaCar. Available online: https://www.academia.edu/43385710/Strategic_ Management_of_BlaBlaCar (accessed on 16 June 2021).

Möhlmann, Mareike. 2015. Collaborative consumption: Determinants of satisfaction and the likelihood of using a sharing economy option again. Journal of Consumer Behaviour 14: 193-207. [CrossRef]

Mtigwe, Bruce. 2006. Theoretical milestones in international business: The journey to international entrepreneurship theory. Journal of International Entrepreneurship 4: 5-25. [CrossRef]

Munkøe, Malthe M. 2017. Regulating the European Sharing Economy: State of Play and Challenges. Intereconomics 52: 38-44. [CrossRef]

Munro, Hugh J., and Nicole E. Coviello. 1995. Growing the Entrepreneurial Firm: Networking for International Market Development. Article in European Journal of Marketing 29: 49-61. [CrossRef]

Nambisan, Satish, Shaker A. Zahra, and Yadong Luo. 2019. Global platforms and ecosystems: Implications for international business theories. Journal of International Business Studies 50: 1464-86. [CrossRef]

Nelson, Richard R., and Sidney G. Winter. 1973. Toward an evolutionary theory of economic capabilities. American Economic Review 63: 440-49. Available online: https://www.jstor.org/stable/1817107 (accessed on 24 July 2021).

Ochieng, Irene A., and Simbarashe Takawira. 2020. Internationalisation Challenges of Sharing Economy Firms: An Emerging African Markets Perspective. Available online: https:/ / www.diva-portal.org/smash/record.jsf?pid=diva2:1442250 (accessed on 14 May 2021).

Oskam, Jeroen, and Albert Boswijk. 2016. Airbnb: The future of networked hospitality businesses. Journal of Tourism Futures 2: $22-42$. [CrossRef]

Oviatt, Benjamin M., and Patricia P. McDougall. 2005. Toward a Theory of International New ventures. Journal of International Business Studies 36: 29-41. [CrossRef]

Parente, Ronaldo, José.-Mauticio. G. Geleilate, and Ke Rong. 2018. The Sharing Economy Globalization Phenomenon: A Research Agenda. Journal of International Management 24: 52-64. [CrossRef]

Paul, Justin, and Alexander Rosado-Serrano. 2019. Gradual Internationalisation vs. Born-Global/International new venture models. International Marketing Review 36: 830-58. [CrossRef]

Peng, Mike W. 2001. The resource-based view and international business. Journal of Management 27: 803-29. [CrossRef]

Penrose, Edith T. 1960. The Growth of the Firm-A Case Study: The Hercules Powder Company. Business History Review 34: 1-23. [CrossRef]

Perren, Rebeca, and Liz Grauerholz. 2015. Collaborative Consumption. International Encyclopedia of the Social and Behavioral Sciences 4: 139-44. [CrossRef]

Petticrew, Mark, and Helen Roberts, eds. 2006. Systematic Reviews in the Social Sciences: A Practical Guide. Hoboken: Blackwell Publishing Ltd. [CrossRef]

Razeghian, Maryam, and Thomas A. Weber. 2019. The advent of the sharing culture and its effect on product pricing. Electronic Commerce Research and Applications 33: 100801. [CrossRef]

Reid, Stan D. 1981. The Decision-Maker and Export Entry and Expansion. Journal of International Business Studies 12: 101-12. [CrossRef]

Ricardo, David. 1891. Principles of Political Economy, and Taxation. London: G. Bell and Sons. [CrossRef]

Richardson, Lizzie. 2015. Performing the sharing economy. Geoforum 67: 121-29. [CrossRef]

Rifkin, Jeremy. 2000. L'Âge de L'accès: Survivre à L'hypercapitalisme. Quebec: Boreal.

Rogers, David. 2016. The Digital Transformation Playbook. New York: Columbia University Press. [CrossRef]

Russo, Francesco, and Maria Luisa Stasi. 2016. Defining the relevant market in the sharing economy. Internet Policy Review 5: 1-13. [CrossRef]

Ruzzier, Mitja, Bostjan Antoncic, Robert D. Hisrich, and Maja Konecnik. 2007. Human capital and SME internationalisation: A structural equation modeling study. Canadian Journal of Administrative Sciences 24: 15-29. [CrossRef]

Sassanelli, Claudio, Monica Rossi, Giuditta Pezzotta, Diego Pacheco, and Sergio Terzi. 2019. Defining lean product service systems features and research trends through a systematic literature review. International Journal of Product Lifecycle Management 12: 37. [CrossRef]

Schor, Juliet. 2016. Debating the sharing economy. Journal of Self-Governance and Management Economics 4: 7. [CrossRef]

Schor, Juliet B., and Steven P. Vallas. 2021. The Sharing Economy: Rhetoric and Reality. Annual Review of Sociology 47: 369-89. [CrossRef]

Seifert, Rene Eugenio. 2010. Meaningful Internationalisation: A Study among the Leaders of Brazilian Smaller Enterprises. Available online: http:/ / etheses.bham.ac.uk/id/eprint/1168/ (accessed on 27 July 2021).

Shaheen, Susan, Adam Stocker, and Marie Mundler. 2017. Online and App-Based Carpooling in France: Analyzing Users and Practices-A Study of BlaBlaCar. In Disrupting Mobility. Edited by Gereon Meyer and Susan Shaheen. Lecture Notes in Mobility. Cham: Springer.

Shaheer, Noman A., and Sali Li. 2020. The CAGE around cyberspace? How digital innovations internationalise in a virtual world. Journal of Business Venturing 35: 105892. [CrossRef]

Shuman, Jeffrey C., and John A. Seeger. 1986. The Theory and Practice of Strategic Management in Smaller Rapid Growth Firms. American Journal of Small Business 11: 7-18. [CrossRef] 
Smith, Adam. 1776. An Inquiry into the Nature and Causes of the Wealth of Nations. New York: Irwin.

Smith, Adele, Paul Ryan, and David G. Collings. 2012. Born global networks: The role of connectors. European Journal of International Management 6: 566. [CrossRef]

Stallkamp, Maximilian, and Andreas P. J. Schotter. 2019. Platforms without borders? The international strategies of digital platform firms. Global Strategy Journal 11: 1-23. [CrossRef]

Statista. 2020. Value of the Global Sharing Economy 2014-2025. Available online: https://www.statista.com/statistics/830986/valueof-the-global-sharing-economy / (accessed on 10 June 2021).

Stokes, Kathleen, Emma Clarence, Lauren Anderson, and April Rinne. 2014. Making Sense of the Uk Collaborative Economy. London: Nesta.

Sundararajan, Arun. 2014. Peer-to-Peer Businesses and the Sharing (Collaborative) Economy: Overview, Economic Effects and Regulatory Issues. Written testimony for the hearing titled The Power of Connection: Peer to Peer Businesses. pp. 1-7. Available online: https:/ / republicans-smallbusiness.house.gov/uploadedfiles/1-15-2014_revised_sundararajan_testimony.pdf (accessed on 10 June 2021).

Sundararajan, Arun. 2016. The Sharing Economy: The End of Employment and the Rise of Crowd-Based Capitalism. Cambridge: MIT Press.

Teece, David J., Gary Pisano, and Amy Shuen. 1997. Dynamic capabilities and strategic management. Strategic Management Journal 18: 509-33. [CrossRef]

Tranfield, David, David Denyer, and Palminder Smart. 2003. Towards a methodology for developing evidence-informed management knowledge by means of systematic review. British Journal of Management 14: 207-22. [CrossRef]

Tsukanova, Tatyana. 2019. Home country institutions and export behaviour of SMEs from transition economies: The case of Russia. European Journal of International Management 13: 811. [CrossRef]

Tussyadiah, Iis. 2016. Factors of satisfaction and intention to use peer-to-peer accommodation. International Journal of Hospitality Management 55: 70-80. [CrossRef]

Uzunca, Bilgehan, J. P. Coen Rigtering, and Pinar Ozcan. 2018. Sharing and shaping: A cross-country comparison of how sharing economy firms shape their institutional environment to gain legitimacy. Academy of Management Discoveries 4: 248-72. [CrossRef]

Vernon, Raymond. 1966. International Investment and International Trade in the Product Cycle. The Quaterly Journal of Economics 80: 190-207. [CrossRef]

Vitkovic, Deni. 2016. The sharing economy: Regulation and the EU competition law. Global Antitrust Review 9: 78-118. Available online: https: / / bit.ly/2SaO972 (accessed on 10 July 2021).

Wernerfelt, Birger. 1984. A resource-Based view of the firm. Strategic Management Journal 5: 171-80. [CrossRef]

Westhead, Paul. 1995. Exporting and non-exporting small firms in Great Britain A matched pairs comparison. International Journal of Entrepreneurial Behaviour \& Research 1: 6-36. [CrossRef]

Wirtz, Jochen, Kevin K. Fung So, Makarand A. Mody, Stephanie Q. Liu, and HaeEun H. Chun. 2019. Platforms in the peer-to-peer sharing economy. Journal of Service Management 30: 452-83. [CrossRef]

Yang, Lie, Zhulei Chen, Ting Liu, Zhe Gong, Yingjian Yu, and Jia Wang. 2013. Global trends of solid waste research from 1997 to 2011 by using bibliometric analysis. Scientometrics 96: 133-46. [CrossRef]

Zalega, Tomasz. 2020. The Sharing Economy and the Behaviour of Young Polish Singles: The Case of BlaBlaCar. Gospodarka Narodowa 304: 105-34. [CrossRef]

Zanoni, Patrizia. 2019. Chapter 6 Labor Market Inclusion Through Predatory Capitalism? The "Sharing Economy," Diversity, and the Crisis of Social Reproduction in the Belgian Coordinated Market Economy. In Work and Labor in the Digital Age. Bingley: Emerald Publishing Limited, pp. 145-64. [CrossRef] 